\title{
Pengaruh Abu Dan Proporsi Pasir-Kompos Di Dalam Media Pada Pertumbuhan Tanaman Sorgum (Sorghum bicolor L.)
}

\section{The Effect of The Addition Of Ash and Sand-Compost Proportion In The Media on The Growth of Sorghum (Sorghum bicolor L.)}

\author{
Andrian isro rahmadi ${ }^{1}$, Tundjung Tripeni Handayani ${ }^{2}$, Martha L Lande ${ }^{2}$ \\ ${ }^{1}$ Mahasiswa Jurusan Biologi - FMIPA Universitas Lampung \\ ${ }^{2}$ Dosen Jurusan Biologi - FMIPA Universitas Lampung \\ Jl. Prof. Soemantri Brodjonegoro No.1, Bandar Lampung 35145 \\ Email: andrianisro86@gmail.com
}

\begin{abstract}
The aim of this experiment was to determine the effect of the addition of ash and sandcompost proportion in the media on the growth of sorghum (Sorghum bicolor L.). The experiment was conducted on December 2015 to January 2016 in the Botanical Laboratory, Biology Department, Faculty of Mathematic and Natural Science, Lampung University, and was conducted in a complete randomized design by using two treatments. The first treatment was the addition of ash in two equivalents (with and without ash), the second treatment was the addition of sand-compost proportion in four equivalents $(2 \mathrm{~kg}$ of sand, $13 / 4 \mathrm{~kg}$ of sand + $1 / 4 \mathrm{~kg}$ of compost, $11 / 2 \mathrm{~kg}$ of sand $+1 / 2 \mathrm{~kg}$ of compost, $1^{1 / 4} \mathrm{~kg}$ of sand $+3 / 4 \mathrm{~kg}$ of compost). The observed variables of the growth were the number of the roots, the crown's length, the wet weight, and the dry weight. The number of the roots was determined by observing the number of the roots present at the base of the stalk of each plants. The length of the crown (cm) was determined by measuring it from the stalk's base to the edge of the longest leaf. The wet weight $(g)$ was determined by measuring the whole part of the plant using an analytical balance. The dry weight $(g)$ was measured after the plants were stored in an oven for three hours in the temperature of $70^{\circ}-80^{\circ} \mathrm{C}$. The result showed that the best growth was obtained from the media with the sand equivalent of 11/4 $\mathrm{kg}$ of sand added with $3 / 4 \mathrm{~kg}$ of compost without ash.
\end{abstract}

Key words: Ash, compost, growth of sorghum (Sorghum bicolor L.), sand

Diterima: 20 Januari 2016, disetujui 31 Maret 2016

\section{PENDAHULUAN}

Sorgum (Sorghum bicolor L.) merupakan tanaman yang berpotensi untuk dikembangkan. Sebab tanaman sorgum memiliki daya adaptasi yang luas, toleran terhadap kekeringan, produktivitas tinggi, dan tahan terhadap hama dan penyakit. Selain budi daya yang mudah, sorgum mempunyai manfaat yang luas, antara lain bisa dimanfaatkan sebagai pakan ternak, bahan pangan, dan bahan industri (Yulita dan Risda 2006). 
Salah satu tipe lahan kering adalah tanah pasir yang memiliki kandungan unsur hara yang rendah, disamping itu tanah pasir tersusun atas $70 \%$ partikel-partikel berukuran besar $(0,02-2 \mathrm{~mm})$, yang menyebabkan tanah pasir bertekstur kasar, hal ini dicirikan adanya ruang pori yang besar diantara butirbutirnya. Kondisi ini menyebabkan tanah pasir menjadi berstruktur lepas dan gembur (Buckman dan Brody, 1982).

Tanah yang terdiri atas partikel besar kurang dapat menahan air. Air dalam tanah akan berinfiltrasi, bergerak ke bawah melalui rongga tanah yang bisa menyebabkan tanaman mudah menjadi layu. Kondisi semacam ini apabila berlangsung terus menerus dapat mematikan tanaman (Dwidjoseputro, 1981). Hal ini akan menimbulkan suatu masalah, apabila budidaya sorgum dilakuakan pada media pasir (tanah berpasir). Oleh karena itu perlu dilakukan uji coba agar budidaya sorgum dapat dilakukan pada media pasir, yakni dengan cara menambahkan abu dan kompos.

Abu adalah molekul yang berupa serbuk yang lembut sisa dari pembakaran. Ada beberapa jenis abu berdasarkan bahan yang dibakar dan tempat pembakarannya, diantaranya ada abu jerami, abu sekam, abu dapur dan abu hasil kegiatan industri rumah tangga. Abu yang digunakan dalam peneitian ini adalah abu yang diperoleh dari pembuatan batu bata (industri rumah tangga). Tekstur yang lembut dari abu menyebabkan abu lebih mudah mengisi pori-pori pada pasir, sehingga dapat membantu memperbaiki struktur media pasir dan mampu mengikat unsur hara yang tersedia didalam media pasir. Abu tidak hanya dapat mengikat unsur hara yang tersedia didalam pasir, tetapi juga dapat meningkatkan retensi air sebab permukaan partikel abu bermuatan negatif sehingga molekul air mudah diikat (Lehman, 2007).

Penggunaan kompos sebagai bahan pembenah tanah (soil conditioner) dapat meningkatkan kandungan bahan organik tanah sehingga mempertahankan dan menambah kesuburan tanah pertanian.

Bahan organik yang dapat digunakan sebagai sumber pupuk organik adalah dari hasil pertanian antara lain berupa jerami, sekam padi, kulit kacang tanah, ampas tebu, pupuk kandang (kotoran sapi, kerbau, ayam, itik, dan kuda) (Kurnia et al., 2001).

Sisa hasil pertanian ini kemudian diolah memalui proses dekomposer atau penguraian dengan bantuan mikroorganisme didalam tanah yang nanti nya akan menjadi kompos yang bisa menjadi menjadi unsurhara yang diperlukan oleh tanaman (Aprijadi, 1989). Tujuan dari penelitian ini adalah untuk mengetahui pengaruh abu dan proporsi pasir- kompos dalam media dapat mempengaruhi perumbuhan tanaman sorgum.

\section{METODE}

Penelitian ini dilaksanakan pada bulan Desember 2015 sampai bulan Januari 2016 di Laboratorium Botani Jurusan Biologi FMIPA Univeristas Lampung. Penelitian ini dilakukan menggunakan metode Rancangan Acak Lengkap (RAL) dengan 2 perlakuan. Perlakuan pertama pemberian abu dengan 2 taraf (diberi abu dan tidak diberi abu), perlakuan yang kedua proporsi pasir-kompos 4 taraf( Pasir $2 \mathrm{~kg}$, Pasir 13/4 $\mathrm{kg}+1 / 4 \mathrm{~kg}$ kompos, Pasir 11/2 kg+1/2 kg kompos, Pasir 11/4 kg+3/4 kg kompos).

Untuk melihat pertumbuhan tanaman sorgum variabel yang diukur adalah dalam penelitian ini adalah panjang tajuk, jumlah akar, berat basah dan berat kering, yang diukur setelah tanaman berumur 30 hari dihitung sejak biji sorgum ditanam.

Panjang tajuk $(\mathrm{cm})$ ditentukan dengan cara mengukur dari pangkal batang sampai ujung daun terpanjang, jumlah akar ditentukan dengan cara melihat banyaknya akar yang keluar dari pangkal batang masing-masing tanaman, berat basah(g) didapat dari penimbangan menggunakan neraca analitik dari seluruh bagian tanaman,berat kering(g) ditimbang dengan neraca analitik setelah semua bagian tanaman dimasukan kedalam oven dengan suhu $70-80^{\circ} \mathrm{c}$ dalam waktu 3 jam.

Data yang diperoleh diuji homogenitasnya dengan uji bartlett. Setelah data homogen dilanjutkan dengan analisis ragam pada taraf nyata 5\%. Jika interaksi kedua faktor perlakuan (abu dan proporsi pasir- 
kompos) tidak nyata, maka dilanjutkan penentuan main effect dengan uji BNT 1\%, jika interaksi kedua faktor perlakuan (abu dan proporsi pasir-kompos) nyata maka dilanjutkan penentuan simple effect dengan uji BNT $1 \%$.

\section{HASIL DAN PEMBAHASAN}

\section{Panjang tajuk}

Berdasarkan analisis ragam pada taraf nyata 5\% menunjukan bahwa komposisi abu dan proporsi pasirkompos berpengaruh nyata terhadap panjang tajuk tanaman sorgum (Tabel 1).

Tabel 1. Uji BNT interaksi antara abu dan proporsi pasir-kompos terhadap panjang tajuk $(\mathrm{cm})$ tanaman sorgum pada usia 30 hari

\begin{tabular}{|c|c|c|c|}
\hline Rasio pasir dan kompos & Tanpa abu & Dengan abu & Rata Rata \\
\hline Pasir 2kg & $\begin{array}{l}39,625 \pm 2,974 \mathbf{c} \\
\text { A }\end{array}$ & $\begin{array}{l}36,925 \pm 8,347 \mathbf{b} \\
\text { A }\end{array}$ & 38,257 \\
\hline Pasir $13 / 4 \mathrm{~kg}+$ kompos $1 / 4 \mathrm{~kg}$ & $\begin{array}{l}63,975 \pm 2,044 \mathbf{b} \\
\text { A }\end{array}$ & $\begin{array}{l}53,762 \pm 17,839 a \\
\text { B }\end{array}$ & 58,869 \\
\hline Pasir $11 / 2 \mathrm{~kg}+$ kompos $1 / 2 \mathrm{~kg}$ & $\begin{array}{l}73,562 \pm 11,889 \mathbf{a} \\
\text { A }\end{array}$ & $\begin{array}{l}58,500 \pm 11,896 \mathbf{a} \\
\text { B }\end{array}$ & 66,031 \\
\hline Pasir 1 1/4 kg +kompos 3/4 kg & $\begin{array}{l}82,250 \pm 2,063 \mathbf{a} \\
\text { A }\end{array}$ & $\begin{array}{l}60,663 \pm 6,839 \mathbf{a} \\
\text { B }\end{array}$ & 71,456 \\
\hline Rata Rata & 64,853 & 52,463 & \\
\hline
\end{tabular}

Keterangan : panjang tajuk $=\mathrm{Y} \pm \mathrm{S} \bar{Y}$

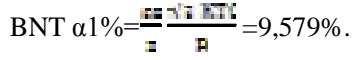

Angka-angka pada baris yang diikuti dengan huruf besar yang sama, menunjukan tidaka berbeda nyata, dan angka-angka pada kolom yang diikuti oleh huruf kecil yang sama menunjukan tidak berbeda nyata menurut uji BNT $1 \%$.

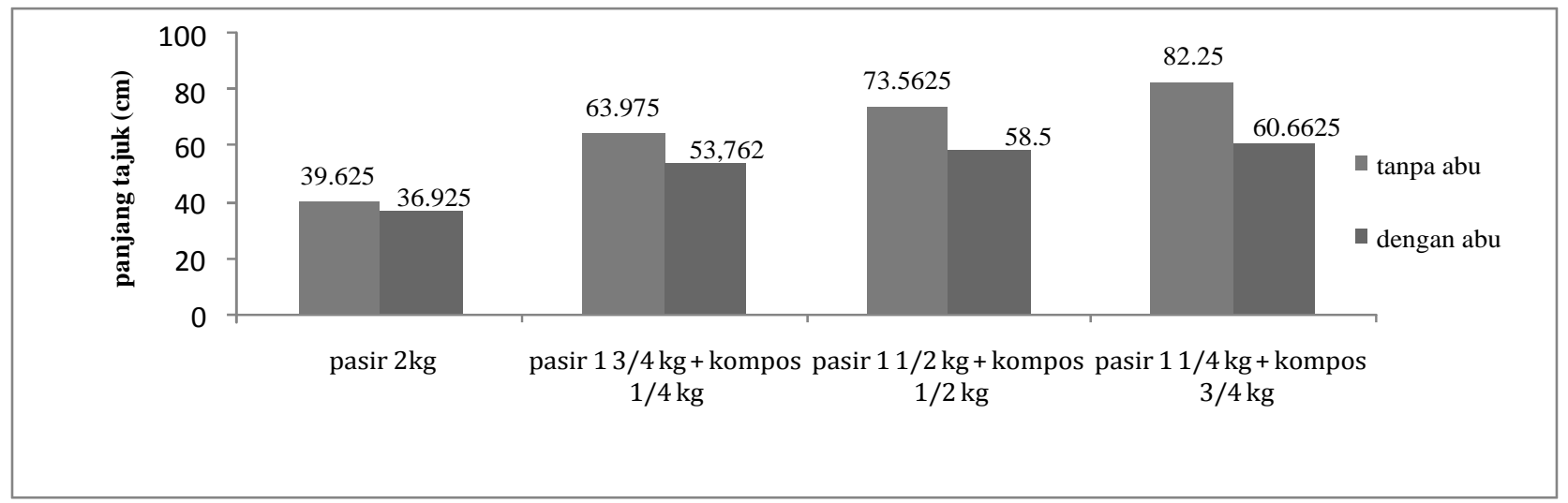

Gambar 1. Grafik simple effect pemberian abu dan proporsi pasir-kompos terhadap panjang tajuk tanaman sorgum berusia 30 hari.

Berdasarkan tabel 1 Uji BNT interaksi antara abu dan proporsi pasir-kompos terhadap panjang tajuk (cm) tanaman sorgum pada usia 30 hari dan Gambar 1:Grafik simple effect pemberian abu dan proporsi pasir-kompos terhadap panjang tajuk tanaman sorgum berusia 30 hari, panjang tajuk tanaman sorgum yang panjang dihasilkan pada media dengan komposisi pasir $1 \frac{1}{1} / 4 \mathrm{~kg}+$ kompos $3 / 4 \mathrm{~kg}$ tanpa abu dengan panjang tajuk 82,250 cm. Pada media dengan komposisi pasir $1 \frac{1}{2} \mathrm{~kg}+$ kompos $1 / 2 \mathrm{~kg}$ tanpa abu, dengan panjang tajuk 73,562 $\mathrm{cm}$. Sedangkan panjang tajuk yang rendah dihasilkan pada media dengan komposisi pasir $2 \mathrm{~kg}$ tanpa abu 39,625 cm dan pada media dengan komposisi pasir $2 \mathrm{~kg}$ dengan abu 36,925 cm.

Panjang tajuk tanaman sorgum pada umur 30 hari yang panjang dihasilkan pada media dengan komposisi pasir $1 \frac{1}{2} \mathrm{~kg}+$ kompos $1 / 2 \mathrm{~kg}$ tanpa abu dengan panjang tajuk $73,562 \mathrm{~cm}$, dan pada media pasir 1 
$1 / 4 \mathrm{~kg}+$ kompos $3 / 4 \mathrm{~kg}$ tanpa abu dengan panjang tajuk $82,250 \mathrm{~cm}$. Sedangkan panjang tajuk yang rendah dihasilkan pada media dengan komposisi pasir $2 \mathrm{~kg}$ tanpa abu 39,625 $\mathrm{cm}$ dan pada media dengan komposisi pasir $2 \mathrm{~kg}$ dengan abu 36,925 $\mathrm{cm}$. Data diatas menunjukan bahwa pemberian kompos pada pada masingmasing media sangat mempengaruhi panjang tajuk tanaman sorgum, semakin sedikit proporsi pasir yang diberikan pada media dan semakin banyak proporsi kompos yang diberikan maka pertumbuhan tanaman sorgum akan semakin baik, sebab kompos merupakan sumber unsur makro dan mikro yang sangat dibutuhkan oleh tanaman untuk membentuk protein, lipi, asam nukleat, dan klorofil yang berfungsi untuk pembentukan gelukosa. Namun apabila didalam media tersebut diberikan abu justru pertumbuhannya semakin terhambat. Karena abu yang digunakan dalam penelitian ini adalah abu yang mengandung getah. Getah yang terkandung didalam abu akan menghambat penyerapan unsur hara makro dan mikro oleh tanaman.

\section{Jumlah akar}

Berdasarkan analisis ragam pada taraf nyata 5\% menunjukan bahwa komposisi abu dan proporsi pasirkompos berpengaruh nyata terhadap jumlah akar tanaman sorgum (Tabel 2).

Tabel 2. Uji BNT interaksi antara abu dan proporsi pasir-kompos terhadap jumlah akar tanaman sorgum pada usia 30 hari

\begin{tabular}{|c|c|c|c|}
\hline Rasio pasir dan kompos & Tanpa abu & Dengan abu & Rata Rata \\
\hline Pasir 2kg & $\begin{array}{l}5,875 \pm 0,057 \mathbf{c} \\
\text { A }\end{array}$ & $\begin{array}{l}4,875 \pm 0,099 \mathbf{b} \\
\text { A }\end{array}$ & 5,375 \\
\hline Pasir $13 / 4 \mathrm{~kg}+\mathrm{kompos} 1 / 4 \mathrm{~kg}$ & $\begin{array}{l}8,875 \pm 0,432 \mathbf{b} \\
\text { A }\end{array}$ & $\begin{array}{l}6,750 \pm 0,396 \mathbf{a} \\
\text { B }\end{array}$ & 7,813 \\
\hline Pasir $1 \frac{1}{2} 2 \mathrm{~kg}+\mathrm{kompos} 1 / 2 \mathrm{~kg}$ & $\begin{array}{l}10,000 \pm 0,125 \mathbf{a b} \\
\text { A }\end{array}$ & $\begin{array}{l}7,375 \pm 0,0989 \mathbf{a} \\
\text { B }\end{array}$ & 8,687 \\
\hline Pasir $1 \frac{1}{1 / 4} \mathrm{~kg}+\mathrm{kompos} 3 / 4 \mathrm{~kg}$ & $\begin{array}{l}11,250 \pm 0,187 \mathbf{a} \\
\text { A }\end{array}$ & $\begin{array}{l}7,750 \pm 0,2292 \mathbf{a} \\
\text { B }\end{array}$ & 9,500 \\
\hline Rata Rata & 9,000 & 6,687 & \\
\hline
\end{tabular}

Keterangan :jumlah akar $=\mathrm{Y} \pm \mathrm{SY}$

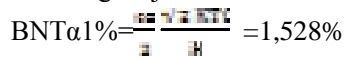

Angka-angka pada baris yang diikuti dengan huruf besar yang sama, menunjukan tidaka berbeda nyata, dan angka-angka pada kolom yang diikuti oleh huruf kecil yang sama menunjukan tidak berbeda nyata menurut uji BNT $1 \%$.

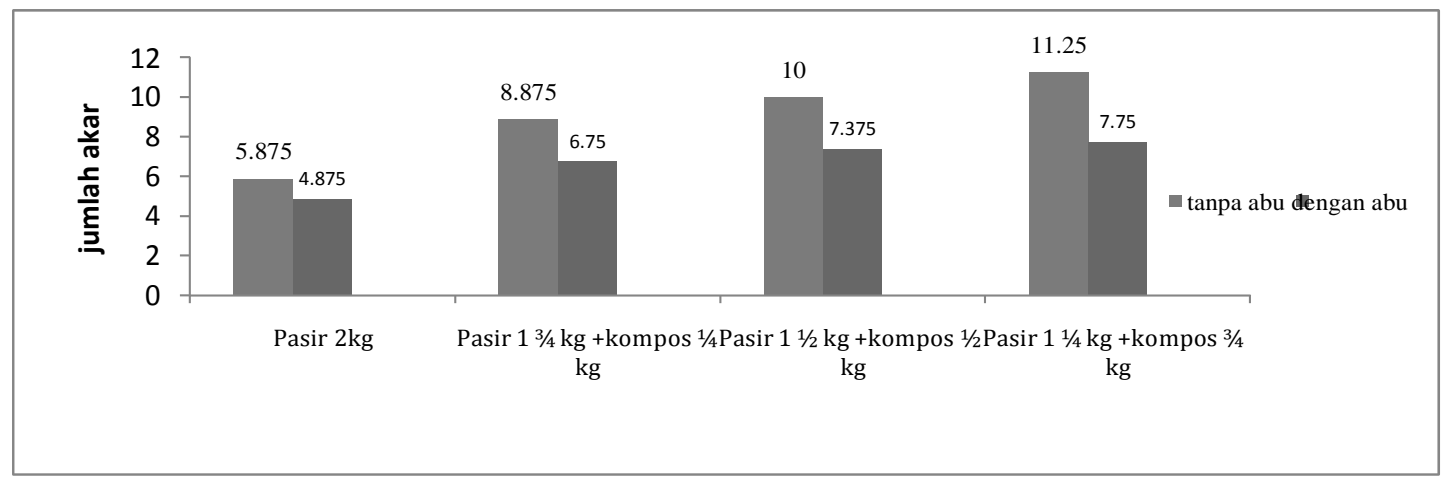

Gambar 2:Grafik simple effect pemberian abu dan proporsi pasir-kompos terhadap jumlah akar tanaman sorgum berusia 30 hari.

Berdasarkan tabel 2 Uji BNT interaksi antara abu dan proporsi pasir-kompos terhadap jumlah akar tanaman sorgum pada usia 30 hari dan Gambar 2:Grafik simple effect pemberian abu dan proporsi pasirkompos terhadap jumlah akar tanaman sorgum berusia 30 hari, jumlah akar tanaman sorgum yang paling 
banyak dihasilkan pada media dengan komposisi media Pasir $1 \frac{1 / 4}{\mathrm{~kg}}+\mathrm{kompos} 3 / 4 \mathrm{~kg}$ tanpa abu dengan jumlah akar tanaman 11,250 . Pada jumlah akar tanaman sorgum rendah dihasilkan pada media dengan komposisi pasir $2 \mathrm{~kg}$ tanpa abu 5,875 dan komposisi pasir $2 \mathrm{~kg}$ dengan abu 4,785.

Hasil penelitian menujukan bahwa jumlah akar tanaman sorgum usia 30 hari paling baik adalah pada media dengan komposisi pasir $1 \frac{1}{4} \mathrm{~kg}+$ kompos $3 / 4 \mathrm{~kg}$ tanpa abu dengan jumlah akar 11,250. Dan jumlah akar tanaman sorgum yang rendah dihasilkan pada media dengan komposisi pasir $2 \mathrm{~kg}$ tanpa abu dengan jumlah akar 5,875 dan komposisi pasir $2 \mathrm{~kg}$ dengan abu 4,875. Hasil ini menunjukan bahwa pemberian kompos pada masing-masing media sangat mempengaruhi jumlah akar pada tanaman sorgum, yakni semakin banyak komposisi kompos yang diberikan maka akan semakin baik pertumbuhan tanaman sorgum. Sebab kompos merupakan sumber unsur hara yang sangat diperlukan oleh tanaman, yaitu unutuk proses pembentukan molekul protein,lipi,dan asam nukleat. Hal ini sesuai dengan pernyataan (Raun dan jonshon 1999) bahwa unsur hara makro dan mikro sangat penting dalam proses pertumbuhan dan perkembangan tanaman.

Namun apabila didalam media terdapat abu, justru pertumbuhan tanaman akan terhambat. Karena dalam penelitian ini abu yang digunakan adalah abu hasil dari pembakaran kayu yang bergetah ( batang pohon karet). Getah yang dikandung didalam abu akan menghambat masuknya unsurhara kedalam tubuh tanaman. Sehingga didalam penelitian ini media yang komposisinya diberi abu akan menghasilkan pertumbuhan yang tidak bagus dibandingkan dengan media yang komposisinya tidak diberi abu. Dalam hal ini bisa dilihat dari jumlah akar yang dihasilkan dari masing-masing media tanam.

\section{Berat basah}

Berdasarkan analisis ragam pada taraf nyata 5\% menunjukan bahwa komposisi abu dan proporsi pasirkompos berpengaruh nyata terhadap berat basah tanaman sorgum (Tabel 3).

Tabel 3. Uji BNT interaksi antara abu dan proporsi pasir-kompos terhadap berat basah (g) tanaman sorgum pada usia 30 hari

\begin{tabular}{|c|c|c|c|}
\hline Rasio pasir dan kompos & Tanpa abu & Dengan abu & Rata Rata \\
\hline Pasir $2 \mathrm{~kg}$ & $\begin{array}{l}1,185 \pm 0,038 \mathbf{d} \\
\mathrm{A}\end{array}$ & $\begin{array}{l}1,027 \pm 0,013 \mathbf{c} \\
\text { A }\end{array}$ & 1,106 \\
\hline Pasir $13 / 4 \mathrm{~kg}+$ kompos $1 / 4 \mathrm{~kg}$ & $\begin{array}{l}4,627 \pm 0,380 \mathbf{c} \\
\text { A }\end{array}$ & $\begin{array}{l}2,400 \pm 0,073 \mathbf{b c} \\
\text { B }\end{array}$ & 3,514 \\
\hline Pasir $11 / 2 \mathrm{~kg}+$ kompos $1 / 2 \mathrm{~kg}$ & $\begin{array}{l}7,280 \pm 0,197 \mathbf{b} \\
\mathrm{A}\end{array}$ & $\begin{array}{l}3,562 \pm 0,043 \mathbf{a b} \\
\text { B }\end{array}$ & 5,421 \\
\hline Pasir $11 / 4 \mathrm{~kg}+$ kompos $3 / 4 \mathrm{~kg}$ & $\begin{array}{l}10,707 \pm 0,254 \mathbf{a} \\
\text { A }\end{array}$ & $\begin{array}{l}4,462 \pm 0,487 \mathbf{a} \\
\text { B }\end{array}$ & 7,585 \\
\hline Rata Rata & 5,950 & 2,863 & \\
\hline
\end{tabular}




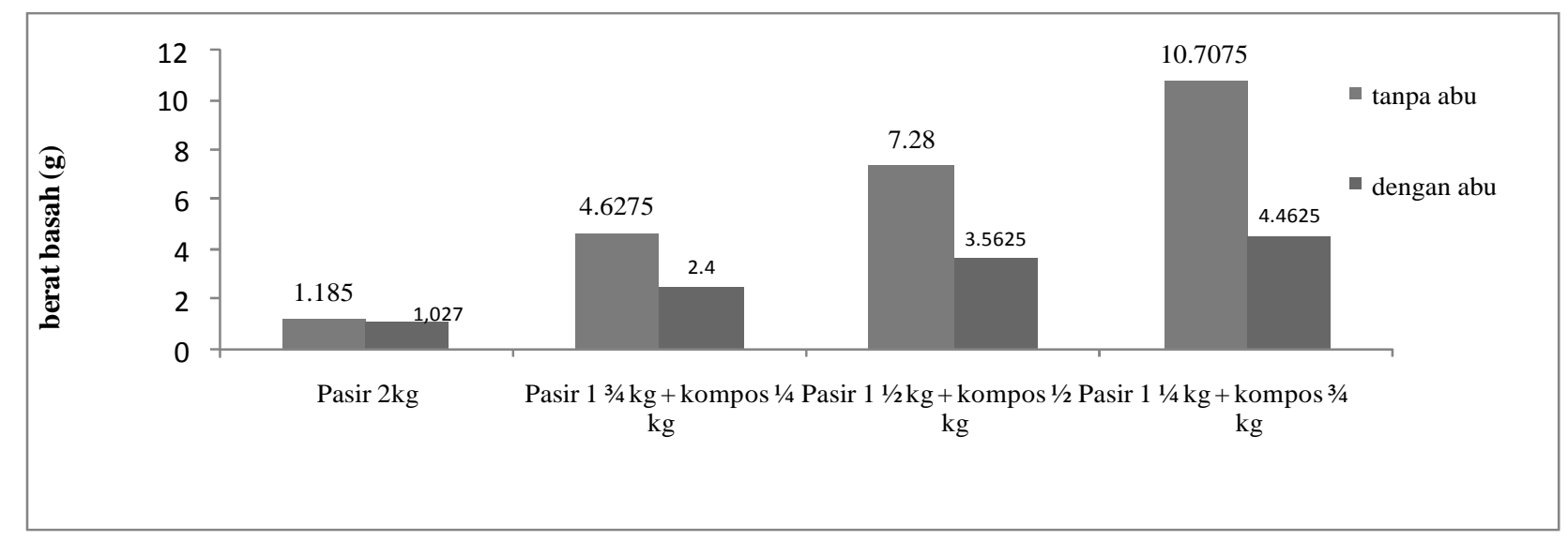

Gambar 3. Grafik simple effect pemberian abu dan proporsi pasir-kompos terhadap berat basah tanaman sorgum berusia 30 hari.

Berdasarkan tabel 3 Uji BNT interaksi antara abu dan proporsi pasir-kompos terhadap berat basah tanaman sorgum pada usia 30 hari dan Gambar 3:Grafik simple effect pemberian abu dan proporsi pasirkompos terhadap berat basah tanaman sorgum berusia 30 hari, berat basah tanaman sorgum yang paling baik dihasilkan pada media dengan komposisi Pasir $1 \frac{1 / 4}{\mathrm{~kg}}$ + kompos $3 / 4 \mathrm{~kg}$ tanpa abu dengan berat basah tanaman $10,707 \mathrm{~g}$. Sedangkan berat basah yang rendah dihasilkan pada media dengan komposisi pasir $2 \mathrm{~kg}$ tanpa abu 1,185 g dan komposisi pasir $2 \mathrm{~kg}$ dengan abu 1,027 g.

Hasil penelitian menujukan bahwa jumlah akar tanaman sorgum usia 30 hari paling baik adalah pada media dengan komposisi pasir $1 \frac{114}{\mathrm{~kg}}+$ kompos $3 / 4 \mathrm{~kg}$ tanpa abu dengan jumlah akar 11,250. Dan jumlah akar tanaman sorgum yang rendah dihasilkan pada media dengan komposisi pasir $2 \mathrm{~kg}$ tanpa abu dengan jumlah akar 5,875 dan komposisi pasir $2 \mathrm{~kg}$ dengan abu 4,875. Hasil ini menunjukan bahwa pemberian kompos pada masing-masing media sangat mempengaruhi jumlah akar pada tanaman sorgum, yakni semakin banyak komposisi kompos yang diberikan maka akan semakin baik pertumbuhan tanaman sorgum. Sebab kompos merupakan sumber unsur hara yang sangat diperlukan oleh tanaman, yaitu unutuk proses pembentukan molekul protein,lipi,dan asam nukleat. Hal ini sesuai dengan pernyataan (Raun dan jonshon 1999) bahwa unsur hara makro dan mikro sangat penting dalam proses pertumbuhan dan perkembangan tanaman.

Namun apabila didalam media terdapat abu, justru pertumbuhan tanaman akan terhambat. Karena dalam penelitian ini abu yang digunakan adalah abu hasil dari pembakaran kayu yang bergetah ( batang pohon karet). Getah yang dikandung didalam abu akan menghambat masuknya unsurhara kedalam tubuh tanaman. Sehingga didalam penelitian ini media yang komposisinya diberi abu akan menghasilkan pertumbuhan yang tidak bagus dibandingkan dengan media yang komposisinya tidak diberi abu. Dalam hal ini bisa dilihat dari jumlah akar yang dihasilkan dari masing-masing media tanam.

\section{Berat kering}

Berdasarkan analisis ragam pada taraf nyata 5\% menunjukan bahwa komposisi abu dan proporsi pasirkompos berpengaruh nyata terhadap berat kering tanaman sorgum (Tabel 4). 
Andrian dkk: Pengaruh Abu Dan Proporsi Pasir-Kompos Di Dalam Media Pada Pertumbuhan Tanaman ...

Tabel 4. Uji BNT interaksi antara abu dan proporsi pasir-kompos terhadap berat kering (g) tanaman sorgum pada usia 30 hari

\begin{tabular}{|c|c|c|c|}
\hline Rasio pasir dan kompos & Tanpa abu & Dengan abu & Rata rata \\
\hline Pasir 2kg & $\begin{array}{l}0,255 \pm 0,001 \mathbf{d} \\
\text { A }\end{array}$ & $\begin{array}{l}0,2 \pm 0,001 \mathbf{d} \\
\text { A }\end{array}$ & 0,227 \\
\hline Pasir $13 / 4 \mathrm{~kg}+$ kompos $1 / 4 \mathrm{~kg}$ & $\begin{array}{l}0,735 \pm 0,004 \mathbf{c} \\
\text { A }\end{array}$ & $\begin{array}{l}0,38 \pm 0,001 \mathbf{c} \\
\text { B }\end{array}$ & 0,557 \\
\hline Pasir $1 \frac{1}{1} 2 \mathrm{~kg}+$ kompos $1 / 2 \mathrm{~kg}$ & $\begin{array}{l}1,200 \pm 0,005 \mathbf{b} \\
\text { A }\end{array}$ & $\begin{array}{l}0,642 \pm 0,001 \mathbf{b} \\
\text { B }\end{array}$ & 0,921 \\
\hline Pasir $1 \frac{1}{1 / 4} \mathrm{~kg}+$ kompos $3 / 4 \mathrm{~kg}$ & $\begin{array}{l}1,732 \pm 0,008 \mathbf{a} \\
\text { A }\end{array}$ & $\begin{array}{l}0,807 \pm 0,002 \mathbf{a} \\
\text { B }\end{array}$ & 1,270 \\
\hline Rata Rata & 0,981 & 0,507 & \\
\hline
\end{tabular}

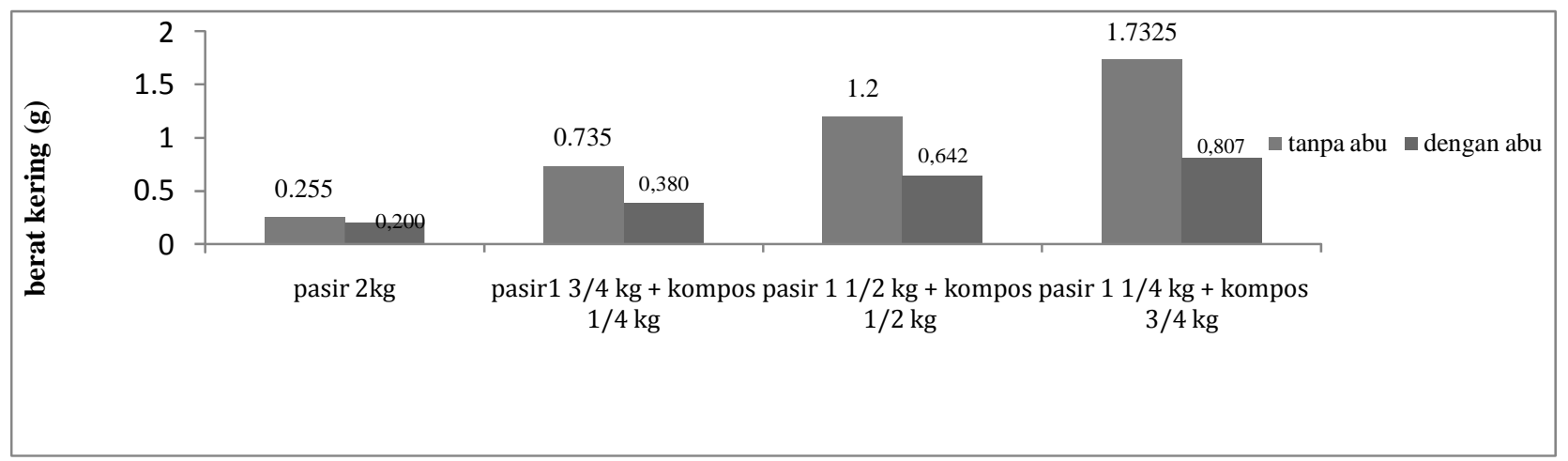

Gambar 4. Grafik simple effect pemberian abu dan proporsi pasir-kompos terhadap berat kering tanaman sorgum berusia 30 hari.

Berdasarkan tabel 4 Uji BNT interaksi antara abu dan proporsi pasir-kompos terhadap berat kering tanaman sorgum pada usia 30 hari dan Gambar 4 :Grafik simple effect pemberian abu dan proporsi pasirkompos terhadap berat kering tanaman sorgum berusia 30 hari, berat kering tanaman sorgum yang paling baik adalah pada media dengan komposisi Pasir $1 \frac{1}{1} / 4 \mathrm{~kg}$ +kompos 3/4 $\mathrm{kg}$ tanpa abu dengan berat kering tanaman $1,732 \mathrm{~g}$, sedangkan berat kering yang rendah dihasilkan pada media dengan komposisi pasir $2 \mathrm{~kg}$ tanpa abu 0,255g dan komposisi pasir $2 \mathrm{~kg}$ dengan abu 0,200g.

Hasil penelitian menunjukan bahwa berat kering tanaman sorgum pada usia 30 hari paling baik yaitu pada media dengan komposisi pasir $1 \frac{1 / 4}{\mathrm{~kg}}+$ dan kompos 3/4 tanpa abu $\mathrm{kg}$ dengan berat kering 1,732 $\mathrm{g}$, sedangkan berat kering tanaman yang rendah dihasilkan pada media dengan komposisi pasir $2 \mathrm{~kg}$ tanpa abu dengan berat kering 0,225 g dan komposisi pasir $2 \mathrm{~kg}$ dengan abu 0,200 g. Hasil tersebut terlihat bahwa pemberian kompos sangatlah membantu pertumbuhan tanaman, karena kompos mampu menyediakan unsur hara yang dibutuhkan oleh tanaman, sedangkan pemberian abu justru menghambat pertumbuhan pertumbuhan tanaman, karena abu yang diberikan pada media mengandung getah, getah yang dikandung didalam abu tersebut menjadi zat ekstraktif yang menyebabkan air dan unsur hara susah diikat. 


\section{KESIMPULAN}

1. Pemberian abu tidak memberikan efek pertumhan tanaman sorgum dengan baik.

2. Pertumbuhan tanaman sorgum paling baik adalah pada media dengan komposisi pasir $1 \frac{1 / 4}{\mathrm{~kg}}+\mathrm{kompos} 3 / 4$ $\mathrm{kg}$ tanpa abu. Sedangkan pertumbuhan tanaman sorgum yang paling rendah adalah pada media pasir $2 \mathrm{~kg}$ tanpa abu.

\section{SARAN}

1. Perlu dilakukan penelitian lebih lanjut tentang kandungan abu yang digunakan dalam penelitian.

2. Abu yang terbuat dari hasil pembakaran kayu yang bergetah tidak dianjurkan untuk digunakan memperbaiki struktur tanah pertanian.

\section{DAFTAR PUSTAKA}

Abidin, Zainal.1990. Dasar-Dasar Pengetahuan Tentang Kandungan Tanaman Karet. Bandung : Angkasa.

Apriadji, Wied Harry. 1989. Memproses Sampah. Seri Teknologi. Cet. keXX11. Penebar Swadaya.

Buckman and Brady, 1982. Ilmu Tanah. PT.Bhatara Karya Aksara. Jakarta.

Demmassabu, S.L. 1989. Pengaruh Pemberian Abu Dapur Terhadap Pertumbuhan Tanaman.

Skripsi 51 Fakultas Pertanian Universitas Sam Ratulangi. Manado.

Dicko, M.H., H. Gruppen, A.S. Traoré, W.J.H van Berkel, and A.G.J Voragen. 2006. Sorghum grain as human food in Africa: relevance of content of starch and amylase activities. African Journal of Biotechnology 5 (5): 384-395.

Kurnia, U., D. Setyorini, T. Prihatini, S. Rochayati, Sutono dan H. Suganda. 2001. Perkembangan dan Penggunaan Pupuk Organik di Indonesia. Rapat Koordinasi Penerapan Penggunaan Pupuk Berimbang dan Peningkatan Penggunaan Pupuk Organik. Direktorat Pupuk dan Pestisida, Direktorat Jendral Bina Sarana Pertanian, Jakarta, Nopember 2001.

Lehmann, J.2007. A handful of carbon. Natur. Vol.477. Nature Publishing Group

Raun,W.R and Johnson,G.V. 1999. Improving Nitrogen Use Efficiency for Cereal Production (Review and Interpretation). Agronomy Journal. 91. 357 - 363

Yulita, R. dan Risda. 2006. Pengembangan sorgum di Indonesia. Direktorat Budi daya Serealia. Ditjen Tanaman Pangan, Jakarta. 